\title{
Relationship between Methylenetetrahydrofolate Reductase (C677T), Factor V Leiden (G1691A), Prothrombin Mutation (G20210A) and Severe Preeclampsia in a Brazilian Population
}

\author{
Thiago F. V. Freire ${ }^{1}$, Gervina B. M. Holanda ${ }^{1}$, Debora M. da Costa ${ }^{1}$, Zuleika S. Sampaio ${ }^{2}$, \\ Francisco E. L. Feitosa ${ }^{2}$, Silvia H. B. Rabenhorst ${ }^{1}$ \\ ${ }^{1}$ Laboratory of Molecular Genetics-LABGEM, Department of Pathology and Legal Medicine, Faculty of Medicine, \\ Federal University of Ceará, Fortaleza, Brazil \\ ${ }^{2}$ Maternidade-Escola Assis Chateaubriand (MEAC), Department of Maternal and Child Health, Faculty of \\ Medicine, Federal University of Ceará, Fortaleza, Brazil \\ Email: edson.lucena@hotmail.com
}

Received 12 May 2014; revised 10 June 2014; accepted 2 July 2014

Copyright (C) 2014 by authors and Scientific Research Publishing Inc. This work is licensed under the Creative Commons Attribution International License (CC BY). http://creativecommons.org/licenses/by/4.0/

(c) ()

\section{Abstract}

Objectives: To better understand the etiologic factors that can influence preeclampsia, we investigated hereditary factors for thrombosis, FV Leiden, F II 20210A mutation and the polymorphism C677T of the MTHFR, as singly and as in association, in a group of women from Ceará stateNortheast Brazil with severe preeclampsia. Material and Methods: We conducted a case-control study. 101 cases of severe preeclampsia were recruited from School Maternity Assis Chateaubriand, a reference Maternity of State of Ceará, Brazil, from December 2009 to December 2010. For clinical correlations, women were interrogated about fetal low weight (less than 2500 grams) and fetal loss in previous pregnancies. Low weight, fetal loss and necessity of neonatal intensive care unit (neonatal ICU) related to current pregnancy were registered. 245 healthy voluntary women were recruited from the blood bank donors to verify the frequency of FV Leiden, FII and MTHFR as a control group. The study was approved by the Committee on Ethics in Human Research of Maternidade Escola Assis Chateubriand and all individuals gave their informed consent to participate in the study. Standard veinipuncture, with EDTA as anticoagulant, was used to collect blood samples. Genomic DNA was extracted, soon after, using a salting out method. Agarose 
gel electrophoresis with ethidium bromide staining was performed to ensure the quality of DNA extraction. Results: The frequencies of FV Leiden and FII mutation carrier were $0.99 \%(1 / 101)$ for both factors in the preeclampsia patients and $1.86 \%(4 / 214)$ and $0.93 \%(2 / 214)$, respectively, in control group. All mutates were heterozygous and concomitance of both mutations was not found. The genotype distribution of the MTHFR C677T in the patients and controls frequencies was in Hardy-Weinberg equilibrium ( $p \leq 0.05)$. No statistical difference was observed between cases and controls in MTHFR genotypes or alleles. Conclusions: The FV Leiden, FII G20210A mutation and MTHFR C677T were not risks for preeclampsia development. FV Leiden and FII G20210A mutations had low frequency in the population studied, which may justify the absence of association.

\section{Keywords}

Preeclampsia, Thrombophilia, Neonatal Outcomes, FV Leiden, Prothrombin, MTHFR

\section{Introduction}

Preeclampsia, an important cause of maternal and fetal morbidity and mortality, is a pregnancy-specific syndrome defined as elevated blood pressure and proteinuria. The etiology of preeclampsia is unknown, but genetic and immunologic factors and abnormal placentation have been proposed to play a causative role [1] [2].

Severe preeclampsia has been shown to be associated with thrombophilia and abnormal placentation increases tendency toward thrombosis influenced by a genetic risk factor [3]-[5]. Therefore, the correlation between genetic risk factor for venous thrombosis and preeclampsia is the focus of some investigations that ask for the causative causes of the preeclampsia [6]-[8]. The hereditary factors frequently associated to thrombophilia are the mutation G1591A in gene of Factor V (Factor V Leiden-FV Leiden), the mutation G20210A in gene of prothromnin (FII) and the polymorphism C677T of methylenetetrahydrofolate reductase (MTHFR) [9].

The FV Leiden variant arises as a result of a point mutation at nucleotide position 1691, resulting in an arginine to a glutamine substitution at position 506 that reduces its sensitivity to inactivation by activated protein C. FV Leiden has been associated with familial thrombophilia and indeed, is the commonest inherited risk factor for venous thrombosis [10] [11].

A G to A transition at nucleotide position 20210 in the 3'-untranslated region of the prothrombin/FactorII (FII) gene is associated with higher plasma prothrombin concentrations, augmented thrombin generation and increased risk of thrombotic disease [10] [11]. This mutation has a wide range of frequency, varying from $0 \%$ to $14 \%$ depending on the ethnic origin [12].

The C677T MTHFR polymorphism is responsible for a decreased MTHFR activity and associated with increased plasma homocysteine concentrations that are induced for a folate metabolism disturbance [13] [14]. Hyperhomocystenemia has been implicated in thrombophilia and preeclampsia [15] [16].

Previous studies results are contradictory to show association of these factors and preeclampsia [17] [18]. Different prevalence of these mutations and polymorphism in different populations depending on ethnic background could explain this contradiction.

Preeclampsia is a disorder found in a large number of pregnant women in our clinical routine. To better understand the etiologic factors that can influence the syndrome, we investigated hereditary factors for thrombosis, FV Leiden, F II 20210A mutation and the polymorphism C677T of the MTHFR, as independent and as in association, in a group of women from Cearástate (Northeast Brazil) with severe preeclampsia. Also, the combination of these parameters and fetal clinical history of low weight, fetal loss and necessity of neonatal intensive care unit (neonatal ICU) were analyzed.

\section{Material and Methods}

\subsection{Subjects}

We conducted a case-control study with women who had severe preeclampsia recruited from Maternidade Escola Assis Chateubriand, a reference Maternity of State of Ceará, Brazil, from December 2009 to December 2010. We identified 101 cases of severe preeclampsia according to the criteria proposed by American College of Obstetricians and Gynecologists, 2002 [19]. 
Preeclampsia was defined as a blood systolic pressure of $140 \mathrm{~mm} \mathrm{Hg}$ or higher, or blood diastolic pressure of $90 \mathrm{~mm} \mathrm{Hg}$ or higher after 20 weeks of gestation in a woman with previously normal blood pressure, and proteinuria of $0.3 \mathrm{~g}$ or more of protein in a 24-hour urine collection (1+ or greater on a urine dipstick test). The severe preeclampsia was defined as a blood pressure $\geq 160 / 110 \mathrm{~mm} \mathrm{Hg}$, or urinary protein excretion $\geq 5 \mathrm{~g}$ (3+ or greater on urine dipstick testing), a platelet count of $<100,000 \mathrm{~mm}^{-3}$ in at least two samples; oliguria ( $<500 \mathrm{~mL}$ per day); persistent and severe symptoms as: altered mental status, headaches, blurred vision or blindness; presence of multiorgan involvement such as pulmonary edema. Also, the combination of hemolysis, abnormal liver enzymes associated with persistent epigastric or upper right quadrant pain [19].

For clinical correlations, women were interrogated about fetal low weight (less than 2500 grams) and fetal loss in previous pregnancies. Low weight, fetal loss and necessity of neonatal intensive care unit (neonatal ICU) related to current pregnancy were registered.

A number of 246 healthy voluntary women were recruited from the blood bank donors to verify the frequency of FV Leiden, FII and MTHFR as a control group. None of them had experienced any past or current thrombotic events or had a family history of venous or arterial thrombosis.

The study was approved by Human Research Ethics Committee of Maternidade Escola Assis Chateubriand and all individuals gave their informed consent to participate in the study.

Standard venipuncture, with EDTA as anticoagulant, was used to collect blood samples. Genomic DNA was extracted, soon after, using a salting out method. Agarose gel electrophoresis with ethidium bromide staining was performed to ensure the quality of DNA extraction.

\subsection{Genotype Analysis}

The genotyping was performed by polymerase chain reaction restriction fragment length polymorphism technique (PCR-RFLP) for all the genes analyzed.

Factor V Leiden: amplification of a 220 pb DNA fragment of the FV gene surrounding nucleotide 1691 was done using primers and conditions as described by Bertina et al. [20]. Subsequently, $10 \mu \mathrm{L}$ of the PCR product was digested with $2.5 \mathrm{U}$ of MNLI to define the genotyping. This enzyme cleaves the normal allele in two sites, creating 3 fragments with $116 \mathrm{pb}, 67 \mathrm{pb}$ and $37 \mathrm{bp}$. Mutate allele abolishes one site resulting in two fragments of $153 \mathrm{pb}$ and $67 \mathrm{pb}$. Heterozygous individuals had both normal and mutant digestion products.

Prothrombine (FII) G20210A mutation: The analysis was performed according to Poort et al. [21]. The amplified PCR product containing $345 \mathrm{pb}$ was digested with HindIII according with the manufactured instruction. The wild type allele remains intact while in the mutated allele a fragment of $332 \mathrm{pb}$ is observed.

MTHFRC677T: The fragment of 198pb from exon 4 of the gene was amplified using primes sequence and conditions described by Froost et al. [22]. The restriction endonuclease HinfI was used to digest the $10 \mu \mathrm{L}$ PCR product to determinate the genotype. The $\mathrm{C}$ to $\mathrm{T}$ transition at the nucleotide 677 (valine variant) creates a new HinfI site which generates fragments of $175 \mathrm{pb}$ and $23 \mathrm{pb}$.

PCR products for all fragments were verified in agarose gel at $2 \%$ ethidium bromide stained and the fragments digested were visualized by silver satined 7\% polyacrylamide gel.

Quality control samples were included in all laboratory analysis and the confirmation of the mutation was done for both FV Leiden and FII. Random samples were reanalyzed for laboratory procedures control.

\subsection{Statistical Analysis}

Differences between genotypes and clinical parameters were calculated with $\chi^{2}$ test. Relative risks were estimated by odds ratio and $\mathrm{p}$ value $<0.05$ were considered statistically significant for all analysis. All confidence intervals were calculated at the 95\% level. The analyses were performed with SPSS software (version 10.0).

\section{Results}

The frequencies of FV Leiden and FII mutation carrier were $0.99 \%$ (1/101) for both factors in the preeclampsia patients and $1.86 \%(4 / 214)$ and $0.93 \%$ (2/214), respectively, in control group. All mutates were heterozygous and concomitance of both mutations were not found. Table 1 shows the characteristics of mutated patients.

The genotype distribution of the MTHFR C677T in the patients and controls are presented in Table 2. All genotypes frequencies were in Hardy-Weinberg equilibrium ( $\leq 0.05)$. No statistical difference was observed between cases and controls in MTHFR genotypes or alleles. 
Table 3 shows the statistical analysis of the association among the neonatal characteristics and maternal genotype. The genotype TT was significantly associated with previous low weight and neonatal ICU both increasing risk. The genotype CC was significantly associated with neonatal ICU as a protection factor.

\section{Discussion}

The low frequency of FV and FII mutations in women with severe preeclampsia (0.99\%, only in heterozygosis) does not show an evident relationship with the development of the disease. These results suggest that thrombophilic predisposing mutations Factor V Leiden and FII G20210A don’t increase risk of preeclampsia in this Brazilian population.

Similar results were previously reported by Dalmaz et al. [23] in Brazilian women, in which no significant association was found between preeclampsia and FV Leiden. However, the association between preeclampsia and FV Leiden varies around the world [2]-[4] [8]. Like this study, any association was found in Netherlands and in English population [24] [25]. However, Hoffman et al. [15] related an increase from three to five times in preeclampsia incidence in carriers of FV Leiden. Also, Dizon-Townson et al. [25] showed that women with FV Leiden mutation are predisposed to severe preeclampsia.

Conflicting data were also reported for FII mutation. Studying an Italian severe preeclamptic women group, Melllo et al. [26] found a frequency of $10.8 \%$ of FII G20210A +/- in preeclamptic women, with a significant association. Kupferminc et al. [27] found a frequency of 8.0\% FII G20210A +/- in Israelipopulation. This association was not significant in spite of the high frequency $(\mathrm{p}=0.14$; $\mathrm{OR}=2.6 ; 95 \% \mathrm{CI}=0.7-10.2)$. Using a multiple logistic regression analysis, the prothrombin mutation was significantly associated with preeclampsia ( $\mathrm{p}$ $=0.03 ;$ OR $=4.5 ; 95 \% \mathrm{CI}=1.12-19$ ). Unlike these studies, our data didn't show any association between preeclampsia and FII mutation. Also, studying FII mutation in a Brazilian population, Dalmaz et al. [23] found a

Table 1. Characteristics of FV Leiden and FII mutated patients.

\begin{tabular}{ccc}
\hline & FATOR II mutation & FATOR V mutation \\
\hline Age & 33 years old & 36 years old \\
Pregnancies & 9 & 6 \\
Births & 3 & 6 \\
Abortions & 6 & 0 \\
Oral contraceptive use & Yes, for 6 years. & Yes, for 3 months. \\
Familiar obstetric complications & No obstetric complications. & Sister had prematurity. \\
Previous obstetric complications & Severe preecampsia in first pregnancy. & No obstetric complications. \\
Comorbidities in pregnancy & Severe preeclampsia. & $1825 \mathrm{~g}$ \\
Neonatal weight & $2820 \mathrm{~g}$ & Severe preeclampsia + chronic hypertension \\
Time at birth & 38 weeks & No weeks and 6 days \\
\hline
\end{tabular}

Table 2. Frequencies of MTHFR genotypes and alleles in women with preeclampsia and controls.

\begin{tabular}{|c|c|c|c|c|}
\hline Genotype/Allele & Preeclamptic group n = 101 & Controls n = 245 & $\mathbf{p}$ & Odds ratio $(95 \% \mathrm{CI})$ \\
\hline CC & $46(45.54 \%)$ & 115 (46.93\%) & 0.813 & $0.95(0.58-1.25)$ \\
\hline CT & 47 (46.53\%) & 112 (45.71\%) & 0.889 & $1.03(0.63$ - 1.69) \\
\hline TT & $8(7.92 \%)$ & 18 (7.34\%) & 0.853 & $1.08(0.42-2.75)$ \\
\hline C & 139 (68.81\%) & 342 (69.79\%) & 0.798 & $0.95(0.66-1.38)$ \\
\hline $\mathbf{T}$ & $63(31.18 \%)$ & 148 (30.20\%) & 0.798 & $1.05(0.72-1.52)$ \\
\hline
\end{tabular}


Table 3. Analysis of the interaction among MTHFR genotypes and alleles in women with preeclampsia and neonatal characteristics.

\begin{tabular}{|c|c|c|c|c|c|c|}
\hline & & $\begin{array}{l}\text { Previous Neonatal } \\
\text { Low Weight } \\
(<2500 \text { g) }\end{array}$ & $\begin{array}{c}\text { Previous Neonatal } \\
\text { Loss }\end{array}$ & Neonatal ICU & $\begin{array}{c}\text { Neonatal Low } \\
\text { Weight }(<2500 \text { g) }\end{array}$ & Neonatal Loss \\
\hline \multirow{3}{*}{$\mathrm{CC}$} & OR & 0.48 & $1.20^{* * *}$ & 0.33 & 0.44 & $0.00^{* * *}$ \\
\hline & $(95 \% \mathrm{CI})$ & $0.09-2.24$ & $0.00-45.41$ & $0.09-1.08$ & $1.77-1.12$ & $0.00-1.09$ \\
\hline & $\mathbf{P}$ & 0.339 & 1.000 & $0.039^{*}$ & $0.057^{* *}$ & 0.248 \\
\hline \multirow{3}{*}{ CT } & OR & 0.74 & 0.00 & 1.53 & 2.47 & 0.00 \\
\hline & $(95 \% \mathrm{CI})$ & $0.16-3.26$ & $0.00-4.93$ & $0.52-4.56$ & $0.59-3.67$ & $0.00-2.68$ \\
\hline & $\mathbf{P}$ & 0.747 & 0.499 & 0.396 & 0.357 & 0.593 \\
\hline \multirow{3}{*}{$\mathbf{T T}$} & OR & 8.70 & $13.14^{* * *}$ & 4.81 & 3.68 & 6.50 \\
\hline & $(95 \% \mathrm{CI})$ & $1.26-59.98$ & $0.00-555.6$ & $0.89-26.43$ & $0.70-21.12$ & $0.00-114.1$ \\
\hline & $\mathbf{P}$ & $0.022^{*}$ & 0.152 & $0.047^{*}$ & 0.114 & 0.221 \\
\hline \multirow{3}{*}{ C } & OR & 0.54 & 0.86 & 0.55 & 0.66 & 0.01 \\
\hline & $(95 \% \mathrm{CI})$ & $0.23-1.27$ & $0.11-5.58$ & $0.29-1.03$ & $0.39-1.11$ & $0.00-0.03$ \\
\hline & $\mathbf{P}$ & 0.484 & $0.033^{*}$ & 0.460 & 0.791 & 0.283 \\
\hline \multirow{3}{*}{$\mathbf{T}$} & OR & 1.34 & 5.64 & 1.27 & 0.92 & 1.72 \\
\hline & $(95 \% \mathrm{CI})$ & $0.54-3.26$ & $0.65-41.21$ & $0.64-2.54$ & $0.49-1.74$ & $0.57-5.09$ \\
\hline & $\mathbf{P}$ & 0.126 & 0.861 & $0.045^{*}$ & $0.098^{* *}$ & $0.000^{*}$ \\
\hline
\end{tabular}

${ }^{*}$ Represents statistically significant association (p value $<0.05$ ); ${ }^{* *}$ Represents a trend to significant association (p value next to 0.05 ); ${ }^{* * *}$ One or more variants for Odds Ratio calculating were zero.

frequency of $4 \%$ in heterozigosis and $1.3 \%$ in homozygosis (control group: $0.7 \%$ in heterozigosis), but no significant associations were found both for GA or AA genotypes ( $\mathrm{OR}=8.11$; 95\% CI $=0.89$ - 73.92).

The possible explanations for the diversity of results among the literature reports related to FV Leiden and FII mutation could be due the ethnic difference of the studied groups, or to the fact that some authors only study severe preeclampsia, when other includes preeclampsia and eclampsia.

The frequency of MTHFR TT (7.92\%) in preeclampsia observed in our study is similar to results from several countries. The difference between our data and the other Brazilian study [28] could be due to the low frequency of the MTHFR TT genotype in the population studied (7.34\% and 12.4\% respectively). In fact, Brazilian population is heterogeneous, formatted by European, African, Asian, as well Indian groups, moreover, with differences in its composition between regions of the country, so the difference found could be due to the differences of ethnic composition. That point is reinforced by the finding of individuals homozygous for FII mutation in Dalmaz study [23]. In the same study, it is found a high incidence (22.7\%) of the TT genotype for the MTHFR in relation to results found in our study (7.92\%).

Worldwide variations in incidence of these thrombophilic genetic factors highlight the importance of screening in different ethnic populations.

Despite of any association between preeclampsia and MTHFR genotype, we found that MTHFR TT increased the risk for neonatal low weight, neonatal loss and necessity of neonatal intensive care unit. There are few studies relating MTHFT polymorphism to neonatal complications in preeclamptic women. The majority of articles have studied this relation in healthy women. Infante-Rivard et al. [29] who were studying healthy women found that there was no relationship between the MTHFR (677) T allele and the risk of intrauterine growth restriction (CT: $\mathrm{OR}=0.84,95 \%$ CI $0.63-1.12$ ) (TT: OR $=1.17,95 \%$ CI $0.72-1.92)$. On the other hand, Martinelli et al. [30] who were studying the association between unexplained or gestational-hypertension-associated fetal growth restriction and MTHFR polymorphism, found a 677 TT genotype frequency of 17 (27.8\%), a similar result to our study, and a significant association.

Folate is an essential nutrient required for the provision of one-carbon sources in biosynthetic processes [31]. It is known that is essential for cell division and growth [32] and deficiencies in folate impair fetal development [33]. It has been reported that folate deficiency during pregnancy increases the risk of the development of neur- 
al-tube defects in the infant. The allele T in 677 MTHFR has reduced enzyme activity. In this way, it could harm fetal conditions in women with preeclampsia, a pathologic condition that independently harms intrauterine homeostasis [34] [35].

\section{Conclusion}

In Summary, in our study we found that FV Leiden, FII G20210A mutation and MTHFR C677T didn't increase risk for preeclampsia development. FV Leiden and FII G20210A mutations had low frequency in the population studied, which may justify the absence of association. Also, the polymorphism of C677T was not associated to preeclampsia. Other genetic and environmental risk factors should contribute to the development of preeclampsia in the population studied. On the other hand, the polymorphism of the C677T in women with preeclampsia was relevant to fetal development, since the TT genotype was associated with low weight and neonatal ICU.

\section{Acknowledgements}

We are grateful to the patients and healthy individuals for participating in our study. We thank Doctors Ana Carolina Muniz Brito, Carolina Buenos Aires Cabral and AlinePires de Freitas from AssisChateubriand Maternity, FUNCAP/CNPq/MS for partial financial support and all scientists from Genetics Molecular Laboratory of Federal University of Ceará.

\section{References}

[1] Steegers, E.A., von Dadelszen, P., Duvekot, J.J. and Pijnenborg, R. (2010) Pre-Eclampsia. Lancet, 376, 631-644. http://dx.doi.org/10.1016/S0140-6736(10)60279-6

[2] de Maat, M.P., de Groot, C.J. (2011) Thrombophilia and Pre-Eclampsia. Seminars in Thrombosis and Hemostasis, 37, 106-110. http://dx.doi.org/10.1055/s-0030-1270335

[3] Deveer, R., Engin-Ustun, Y., Akbaba, E., Halisdemir, B., Cakar, E., Danisman, N., Mollamahmutoglu, L., Yesilyurt, A. and Candemir, Z. (2012) Association between Pre-Eclampsia and Inherited Thrombophilias. Fetal Pediatric Pathology, 32, 213-217.

[4] Vucić, N., Frleta, M., Petrović, D. and Ostojić, V. (2009) Thrombophilia, Preeclampsia and Other Pregnancy Complications. Acta Medica Croatica, 63, 297-305.

[5] Rath, W. (2011) Pre-Eclampsia and Inherited Thrombophilia: A Reappraisal. Seminars in Thrombosis and Hemostasis, 37, 118-124. http://dx.doi.org/10.1055/s-0030-1270337

[6] Ahn, H., Park, J., Gilman-Sachs, A. and Kwak-Kim, J. (2011) Immunologic Characteristics of Preeclampsia, a Comprehensive Review. American Journal of Reproductive Immunology, 65, 377-394. http://dx.doi.org/10.1111/j.1600-0897.2010.00913.x

[7] Rojas, J.C., Luna, M., Rangel-Nava, H., Baños, D. and Collados, M.T. (2010) Genetic Thrombophilia and Markers of Endothelial Activation in Patients with Preeclampsia. Ginecología y Obstetricia de México, 78, 401-409.

[8] Best, L.G., Dorsam, S.T., Nadeau, M., Burd, L. and Anderson, C.M. (2009) Genetic Thrombophilia Variants and Risk for Preeclampsia among American Indians. Hypertension in Pregnancy, 28, 85-94. http://dx.doi.org/10.1080/10641950802419887

[9] Kjellberg, U., van Rooijen, M., Bremme, K. and Hellgren, M. (2010) Factor V Leiden Mutationand Pregnancy-Related Complications. American Journal of Obstetrics Gynecology, 203, 469.e1-e8.

[10] Almawi, W.Y., Keleshian, S.H., Borgi, L., Fawaz, N.A., Abboud, N., Mtiraoui, N. and Mahjoub, T. (2005) Varied Prevalence of Factor V G1691A (Leiden) and Prothrombin G20210A Single Nucleotide Polymorphisms among Arabs. Journal of Thrombosis and Thrombolysis, 20, 163-168. http://dx.doi.org/10.1007/s11239-005-3550-4

[11] Franco, R.F., Trip, M.D., Ten Cate, H., et al. (1999) The 20210 G A Mutation in the 3'-Untranslated Region of the Prothrombin Gene and the Risk for Arterial Thrombotic Disease. British Journal of Haematology, 104, 50-54. http://dx.doi.org/10.1046/j.1365-2141.1999.01149.x

[12] de Vries JI, Kist WJ, Hague WM. (2009) Confounded Thrombophilia Studies in Preeclampsia. American Journal of Obstetrics Gynecology, 201, e11-e12. http://dx.doi.org/10.1016/j.ajog.2009.05.017

[13] Calvert, H. (1999) An Overview of Folate Metabolism: Features Relevant to the Action and Toxicities of Antifolate Anticancer Agents. Seminars in Oncology, 26, 3-10.

[14] Carmel, R., Green, R., Rosenblatt, D.S. and Watkins, D. (2003) Update on Cobalamin, Folate, and Homocysteine. Hematology-American Society of Hematology Education Program, 2003, 62-81. 
http://dx.doi.org/10.1182/asheducation-2003.1.62

[15] Hoffmann, E., Hedlund, E., Perin, T. and Lyndrup, J. (2012) Is Thrombophilia a Risk Factor for Placenta-Mediated Pregnancy Complications? Archives of Gynecology and Obstetrics, 286, 585-589. http://dx.doi.org/10.1007/s00404-012-2342-2

[16] Benedetto, C., Marozio, L., Tavella, A.M., Salton, L., Grivon, S. and Di Giampaolo, F. (2010) Coagulation Disorders in Pregnancy: Acquired and Inherited Thrombophilias. Annals of the New York Academy of Sciences, 1205, 106-117. http://dx.doi.org/10.1111/j.1749-6632.2010.05674.x

[17] Kahn, S.R., Platt, R., McNamara, H., Rozen, R., Chen, M.F., Genest, Jr., J., Goulet, L., Lydon, J., Seguin, L., Dassa, C., Masse, A., Asselin, G., Benjamin, A., Miner, L., Ghanem, A. and Kramer, M.S. (2009) Inherited Thrombophilia and Preeclampsia within a Multicenter Cohort: The Montreal Preeclampsia Study. American Journal of Obstetrics Gynecology, 200, 151.e1-e9 Discussion

[18] Kupferminc, M.J., Fait, G., Many, A., Gordon, D., Eldor, A. and Lessing, J.B. (2000) Severe Pre-Eclampsia and High Frequency on Genetic Thrombophilic Mutations. Obstetrics Gynecology, 96, 45-49. http://dx.doi.org/10.1016/S0029-7844(00)00861-9

[19] ACOG Committee on Practice Bulletins-Obstetrics (2002) ACOG Practice Bulletin. Diagnosis and Management of Preeclampsia and Eclampsia. Obstetrics Gynecology, 77, 67-75.

[20] Bertina, R.M., Koeleman, B.P.C., Koster, T., Rosendaal, F.R., Dirven, R.J., de Ronde, H., van der Velden, P.A. and Reitsma, P.H. (1994) Mutation in Blood Coagulation Factor V Associated with Resistance to Activated Protein C. $\mathrm{Na}$ ture, 369, 64-67. http://dx.doi.org/10.1038/369064a0

[21] Poort, S.R., Rosendaal, F.R. and Reitsma, P.H. (1996) A Common Genetic Variation in the 3'-Untranslated Region of the Prothrombin Gene Is Associated with Elevated Plasma Prothrombin Levels and an Increase in Venous Thrombosis. Blood, 88, 3698-3703.

[22] Frosst, P., Blom, H.J., Milos, R., Goyette, P., Sheppard, C.A., Matthews, R.G., Boers, G.J., den Heijer, M., Kluijtmans, L.A., van den Heuvel, L.P., et al. (1995) A Candidate Genetic Risk Factor for Vascular Disease: A Common Mutation in Methylenetetrahydrofolate Reductase. Nature, 10, 111-113.

[23] Dalmaz, C.A., Santos, K.G., Bottom, M.R., Tedoldi, C.L. and Roisenberg, I. (2006) Relationship between Polymorphisms in Thrombophilic Genes and Preeclampsia in a Brazilian population. Blood Cells, Molecules, and Diseases, 37, 107-110. http://dx.doi.org/10.1016/j.bcmd.2006.07.005

[24] O’Shaughnessy, K.M., Fu, B., Ferraro, F., Lewis, I., Downing, S. and Morris, N.H. (1999) Factor V Leiden and Thermolabile Methylenetetrahydrofolate Reductase Gene Variants in an East Anglian Preeclampsia Cohort. Hypertension, 33, 1338-1341. http://dx.doi.org/10.1161/01.HYP.33.6.1338

[25] De Groot, C.J.M., Bloemenkamp, K.W.M., Duvekot, E.L., Helmerhorst, F.M., Bertina, R.M., Van Der Meer, F., De Ronde, H., Oei, S.G., Kanhai, H.H.H. and Rosendaal, F.R. (1999) Preeclampsia and Genetic Risk Factors for Thrombosis: A Case Control Study. American Journal of Obstetrics \& Gynecology, 181, 975-980. http://dx.doi.org/10.1016/S0002-9378(99)70335-2

[26] Mello, G., Parrett, E., Mario, L., Pizzi, C., Lojacono, A., Frusca,T., Facchinetti, F. and Benedetto, C. (2007) Thrombophilia Is Significantly Associated with Severe Preeclampsia Results of a Large-Scale, Case-Controlled Study. Hypertension, 46, 1270-1274.

[27] Kupferminc, M.J., Eldor, A., Stemman, N., Many, A., Bar-Arn, A., Jaffa, A., et al. (1999) Increased Frequency of Genetic Thrombophilia in Women with Complications of Pregnancy. The New England Journal of Medicine, 340, 9-13. http://dx.doi.org/10.1056/NEJM199901073400102

[28] Figueiro Filho, E.A., Oliveira, V.M., Coelho, L.R. and Brenda, I. (2012) Serum Markers of Inherited Trombophilia and Antiphospholipid Antibodies in Pregnant Women with Previous History of Severe Pre-Eclampsia. Revista Brasileira de Ginecologia e Obstetrícia, 34, 40-46.

[29] Infante-Rivard, C., Rivard, G.E., Yotov, W.V., Genin, E., Guiguet, M., Weinberg, C., Gauthier, R. and Feoli-Fonseca, J.C. (2002) Absence of Association of Thrombophilia Polymorphisms with Intrauterine Growth Restriction. The New England Journal of Medicine, 347, 19-25. http://dx.doi.org/10.1056/NEJM200207043470105

[30] Martinelli, P., Grandone, E., Colaizzo, D., et al. (2001) Familial Thrombophilia and the Occurrence of Fetal Growth Restriction. Haematologica, 86, 428-431.

[31] Kalhan, S.C. (2013) One-Carbon Metabolism, Fetal Growth and Long-Term Consequences. Nestlé Nutrition Workshop Series, 74, 127-38. http://dx.doi.org/10.1159/000348459

[32] Nazki, F.H., Sameer, A.S. and Ganaie, B.A. (2014) Folate: Metabolism, Genes, Polymorphisms and the Associated Diseases. Gene, 533, 11-20. http://dx.doi.org/10.1016/j.gene.2013.09.063

[33] Guéant, J.L., Namour, F., Guéant-Rodriguez, R.M. and Daval, J.L. (2013) Folate and Fetal Programming: A Play in Epigenomics? Trends in Endocrinology and Metabolism, 24, 279-289. http://dx.doi.org/10.1016/j.tem.2013.01.010 
[34] Black, R.E., Victora, C.G., Walker, S.P., Bhutta, Z.A., Christian, P., de Onis, M., Ezzati, M., Grantham-McGregor, S., Katz, J., Martorell, R., Uauy, R., Maternal and Child Nutrition Study Group (2013) Maternal and Child Undernutrition and Overweight in Low-Income and Middle-Income Countries. Lancet, 382, 427-451. http://dx.doi.org/10.1016/S0140-6736(13)60937-X

[35] van Uitert, E.M. and Steegers-Theunissen, R.P. (2013) Influence of Maternal Folate Status on Human Fetal Growth Parameters. Molecular Nutrition Food Research, 57, 582-595. http://dx.doi.org/10.1002/mnfr.201200084 
Scientific Research Publishing (SCIRP) is one of the largest Open Access journal publishers. It is currently publishing more than 200 open access, online, peer-reviewed journals covering a wide range of academic disciplines. SCIRP serves the worldwide academic communities and contributes to the progress and application of science with its publication.

Other selected journals from SCIRP are listed as below. Submit your manuscript to us via either submit@scirp.org or Online Submission Portal.
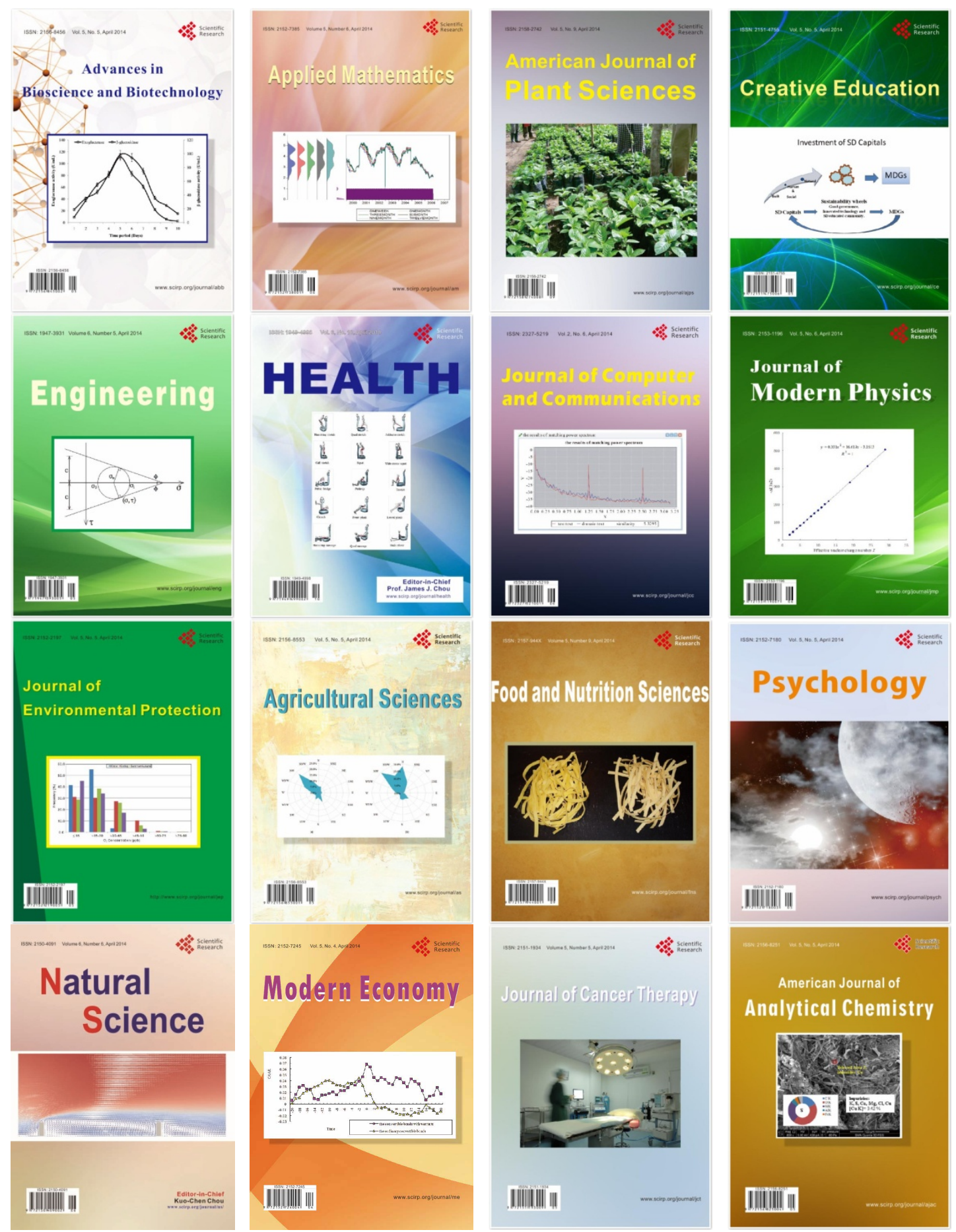